\title{
A Holocene palaeoenviromental study of a sediment core from Ile de la Possession, lles Crozet, sub-Antarctica
}

\author{
MARIJKE OOMS ${ }^{\mathbf{1}}$, BART VAN DE VIJVER ${ }^{2}$, STIJN TEMMERMAN ${ }^{1}$ and LOUIS BEYENS ${ }^{1}$ \\ ${ }^{1}$ University of Antwerp (CDE), Department of Biology, Research Group of Polar Ecology, Limnology and Geomorphology, \\ Universiteitsplein 1, B-2610 Wilrijk, Belgium \\ ${ }^{2}$ National Botanic Garden of Belgium, Department of Bryophyta \& Thallophyta, Domein van Bouchout, B-1860 Meise, Belgium \\ marijke.ooms@ua.ac.be
}

\begin{abstract}
Ile de la Possession is one of the few islands in the southern Indian Ocean, making the island a valuable place to reconstruct past environmental and climatic changes. In this study a peat sediment core was analysed to reconstruct the changes that occurred before, during and after the eruption of the Morne Rouge $\left(10000-5500{ }^{14} \mathrm{C}\right.$ yr $\left.\mathrm{BP}\right)$ volcano. In addition to sedimentological analyses, diatom communities were used to reconstruct humidity and altitude, based on existing transfer functions. Radiocarbon dating of a tephra layer showed that the Morne Rouge volcano erupted between 6700-6600 cal. yr BP, giving a much more precise time scale for this event. The eruption was preceded by a tsunami flooding, indicated by the high numbers of marine diatoms found immediately before the tephra layer. After the eruption pioneer diatom species recolonized the coring site. Evidence is presented of the late climatic optimum around 3050 cal. yr BP, preceded by a cooling event until $6600 \mathrm{cal}$. yr вP. Nutrient input from elephant seals and wandering albatrosses obscured the climate signal for the last $600 \mathrm{cal} \mathrm{yr}$ BP.
\end{abstract}

Received 3 August 2010, accepted 14 February 2011, first published online 15 April 2011

Key words: diatom, palaeoecology, volcanic eruption

\section{Introduction}

Although the Southern Hemisphere oceans play a key role in global climate change (Hodgson \& Sime 2010), relatively few palaeoclimate records exist from there in comparison to the Northern Hemisphere (Pahnke \& Sachs 2006). The Southern Hemisphere palaeo-reconstruction database (NOAA Paleoclimatology Program http://www.ncdc.noaa.gov/paleo/ recons.html, accessed 4 April 2010) consists mainly of studies on deep sea sediment cores (Stott et al. 2007). The few terrestrial Holocene records of the Antarctic region are mainly concentrated in East Antarctica (Verleyen et al. 2010), the Antarctic Peninsula (Bentley et al. 2009), the maritime Antarctic and sub-Antarctic islands (e.g. Jones et al. 2000, Van der Putten et al. 2004) and are reviewed by Ingólfsson et al. (1998) and Hodgson et al. (2004). In the southern Indian Ocean sector, terrestrial Holocene palaeoecological data are scarce and restricted to a few climate reconstructions of the Iles Kerguelen mainly focusing on palynological data (Bellair-Roche \& Delibrias 1967, Young \& Schofield 1973, Larson 1974, Bellair-Roche 1976a, 1976b). Only three studies are known from Ile de la Possession (Iles Crozet). In 1972, Bellair-Roche reported a sequence of undated warmer and cooler events based on pollen and botanical macro remains in a peat core of the Vallée des Branloires. Vincke (2006) investigated the sub fossil testate amoebae assemblages in a peat core from the same valley. The studied core, however, did not represent a complete sequence, due to a gap of more than 4500 years between 5400 and $700{ }^{14} \mathrm{C}$ yr BP. Finally,
Van der Putten et al. (2008) investigated a 6200 cal. yr вP old peat core from the Morne Rouge volcano crater based on moss remains, diatoms and geochemistry.

Despite the important information provided by these environmental reconstructions on Ile de la Possession, none of them reported on the impact of the most recent eruption of the Morne Rouge volcano. Moreover, the exact date of this eruption was only roughly estimated to have occurred somewhere between 10000 and $5800{ }^{14} \mathrm{C}$ yr BP (Giret et al. 2003, Van der Putten et al. 2008). The aim of the present study was therefore to carry out a high-resolution environmental reconstruction before, during and after the eruption event. Environmental and climatic changes in the terrestrial environment were inferred from sedimentological and diatom-based proxies and applying previously developed diatom transfer functions for moisture and temperature (Van de Vijver \& Beyens 1999, Gremmen et al. 2007).

\section{Site description}

The Iles Crozet $\left(45^{\circ} 48^{\prime}-46^{\circ} 26^{\prime} \mathrm{S}, 50^{\circ} 14^{\prime}-52^{\circ} 15^{\prime} \mathrm{E}\right)$ is a group of five small volcanic islands located in the southern Indian Ocean, north of the Polar Front at about $2400 \mathrm{~km}$ south-east of the South African coast (Fig. 1). The islands have a cold oceanic climate with a mean annual air temperature of about $5^{\circ} \mathrm{C}$ and an annual precipitation usually exceeding $2400 \mathrm{~mm}$, mostly in the form of rain, snow and mist. Strong winds, coming from the west and north-west sweep the 

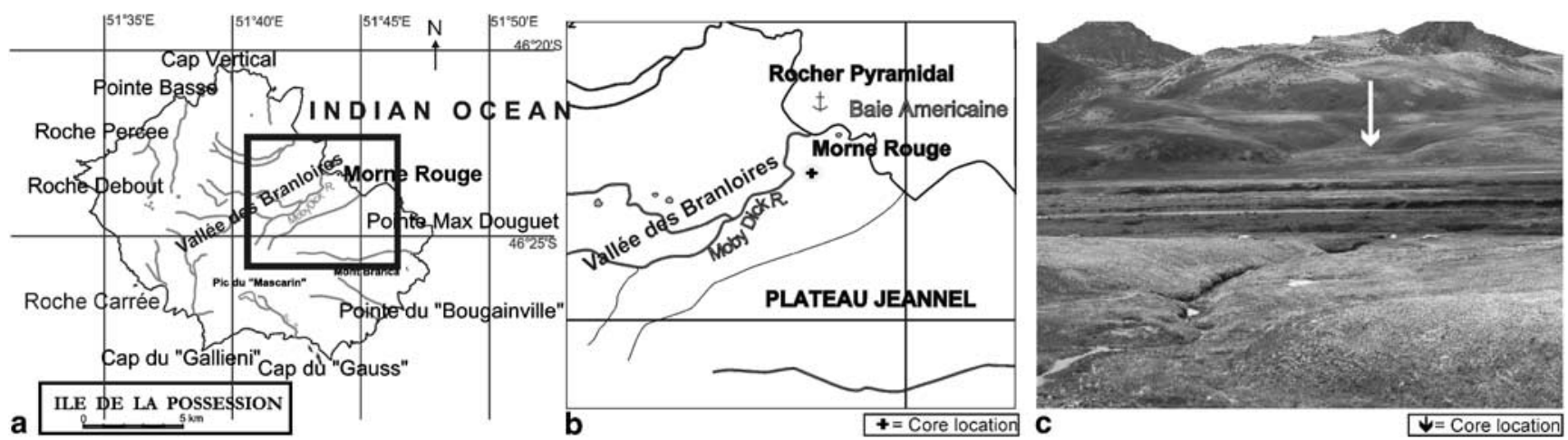

Fig. 1. a. Map of Ile de la Possession with b. detail of the coring location, and c. a site photograph.

islands (records from the east coast of Ile de la Possession) (Frenot 1986). Ile de la Possession is the largest island $\left(146 \mathrm{~km}^{2}\right)$ of the Iles Crozet (Fig. 1a). Its last volcanic phase (Phase V) occurred during the past $10000{ }^{14} \mathrm{C}$ yr BP (Giret et al. 2003, Van der Putten et al. 2008) forming several cones on the island such as Morne Rouge $(116 \mathrm{~m})$, Mont Branca $(383 \mathrm{~m})$ and Mont des Cratères $(700 \mathrm{~m})$.

The eastern part of the island is characterized by several larger valleys, probably of glacial origin (such as Vallée des Branloires, Vallée de la Hébé, Baie du Petit Caporal), intercepted by plateaus with steep slopes. In contrast, the western part of Ile de la Possession has a totally different topography with mountain ranging up to $934 \mathrm{~m}$ altitude (Frenot 1986).

The vegetation consists of 22 vascular plants (Frenot 1986) including four ferns and two Lycopodium species. Apart from this native flora, more than 60 introduced species have been recorded on the island (Frenot et al. 2001), most of them only near the permanent base Alfred Faure and several cabins on the island. Furthermore, more than 100 bryophyte species have been observed although Sphagnum species are completely absent (Van de Vijver et al. 2002). The climatic conditions favour extensive peat formation at low altitudes.

\section{Material and methods}

\section{Coring}

During the summer of 2004-05, a $203 \mathrm{~cm}$ long sediment core was sampled on the south-western slope of the Morne Rouge volcano located at the end of the Vallée des Branloires, close to the Indian Ocean (Frenot 1986). The volcano (max. altitude $116 \mathrm{~m}$ ) is characterized by steep cliffs bordering the ocean and a gentle slope towards the Vallée des Branloires. The latter slope is composed of several depressions and ridges. The coring site $\left(46^{\circ} 23^{\prime} 35.45^{\prime \prime} \mathrm{S}-51^{\circ} 48^{\prime} 28.85^{\prime \prime} \mathrm{E}\right)$ (Fig. 1b) was chosen in one of these small, slightly elevated side depressions at an altitude of $12 \mathrm{~m}$ since the latter was probably created following the volcanic eruption and thus most probably would contain evidence of this eruption. The depression is formed by a $10 \mathrm{~m}$ wide, $150 \mathrm{~m}$ long and very gentle slope down valley in a NNW-SE direction. It is bordered by relatively high, vegetated ridges. The depression was vegetated with semi-wet tundra dominated by Sanionia uncinata (Hedw.) Loeske and Agrostis magellanica Lam. (Vincke 2006). The sediment core was sampled by pushing a $10 \mathrm{~cm}$ diameter PVC tube into the soil. The resulting core was subdivided into three sections for shipping. In the laboratory, these sections were split lengthwise followed by a description of the core lithostratigraphy. One-half of the core was sliced into $1 \mathrm{~cm}$ thick samples. Every three slices a sample was selected, resulting in a total of 73 samples available to be processed for diatom, bulk density and Loss-on-Ignition analyses.

\section{Radiometric dating}

Ten samples for AMS ${ }^{14} \mathrm{C}$ dating were taken near stratigraphical boundaries. The ${ }^{14} \mathrm{C}$ analysis was done by the Royal Institute for the study and conservation of Belgium's Artistic Heritage (KIKIRPA) in Brussels. Calibration of the radiocarbon dates was performed using Oxcal v4.1.7 (Bronk-Ramsey 2009) and the Southern Hemisphere Atmospheric Data (McCormac et al. 2004). The methods for the radiocarbon dating were explained in Van der Putten et al. (2004).

\section{Bulk density and Loss-On-Ignition (LOI)}

Seventy-one samples were selected for bulk density analysis, but only 52 were actually analysed due to the difficulty of taking samples of a fixed volume from a stony layer and problems of getting samples of wet fibrous peat that compacted during sampling.

Samples for bulk density analysis and Loss-On-Ignition were taken with a corer of $0.5 \mathrm{~cm}^{3}$ and treated following Last \& Smol (2001).

\section{Diatom analysis}

Diatoms are one of the most abundant algal groups in the Antarctic Region, both in number of species and individuals. 
Table I. Results of the radiometric dating. Bulk sediments were used for the radiometric analyses.

\begin{tabular}{|c|c|c|c|c|}
\hline Code & $\begin{array}{l}\text { Depth below surface } \\
\qquad(\mathrm{cm})\end{array}$ & $\begin{array}{c}\text { Radiocarbon date } \\
\text { yr BP }\end{array}$ & $\begin{array}{c}\text { Calibrated date } \\
\text { yr BP }\end{array}$ & $\begin{array}{c}\text { Mean calibrated date } \\
\text { yr BP }\end{array}$ \\
\hline KIA-31345 & 44 & $240 \pm 45$ & 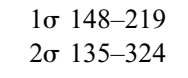 & 184 \\
\hline KIA-31347 & 83 & $680 \pm 25$ & $\begin{array}{l}1 \sigma 561-605 \\
2 \sigma 558-654\end{array}$ & 583 \\
\hline KIA-31348 & 133 & $1470 \pm 40$ & 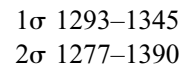 & 1319 \\
\hline KIA-31346 & 141 & $1270 \pm 30$ & $\begin{array}{ll}1 \sigma & 1078-1175 \\
2 \sigma & 1059-1187\end{array}$ & 1127 \\
\hline KIA-31332 & 152 & $2980 \pm 30$ & $\begin{array}{l}1 \sigma 3002-3084 \\
2 \sigma 2961-3210\end{array}$ & 3043 \\
\hline KIA-31356 & 159 & $4265 \pm 35$ & $\begin{array}{l}1 \sigma 4702-4760 \\
2 \sigma 4616-4767\end{array}$ & 4731 \\
\hline KIA-31361 & 168 & $5840 \pm 40$ & $\begin{array}{l}1 \sigma 6533-6652 \\
2 \sigma 6467-6678\end{array}$ & 6593 \\
\hline KIA-31330 & 190 & $5965 \pm 40$ & $\begin{array}{l}1 \sigma 6673-6757 \\
2 \sigma 6638-6859\end{array}$ & 6715 \\
\hline KIA-31355 & 197 & $6110 \pm 40$ & $\begin{array}{l}1 \sigma 6849-6972 \\
2 \sigma 6779-7020\end{array}$ & 6911 \\
\hline
\end{tabular}

Compared to the diatom flora on larger landmasses, the non-marine diatom composition on Ile de la Possession is rather species-poor with less than 250 species known (Van de Vijver et al. 2002). Nevertheless, they have been found in almost all habitat types present on the island. Specialized diatom species that are able to tolerate different extreme environmental conditions (e.g. drought, limited nutrient levels, $\mathrm{pH}$ changes), allow this group to be excellent indicators of palaeo-environmental changes and, because of their silica exoskeleton, they are usually well-preserved in sediment and peat records (Stoermer \& Smol 1999).

Seventy-three samples were processed for diatom analysis. The samples were dried in an oven at $36^{\circ} \mathrm{C}$ for $24 \mathrm{~h}$. Approximately $0.5 \mathrm{~g}$ of dried material of each sample was subsequently prepared following Van der Werff (1955). Lycopodium spores (Stockmarr 1971) were added to estimate total diatom concentration expressed as valves per gramme dry sediment (VGS). Cleaned diatom valves were mounted in Naphrax ${ }^{\circledR}$. In each sample a total of 500 diatom valves were counted on random transects using an Olympus BX 51 microscope equipped with Differential Interference Contrast optics (DIC-Nomarski). Broken valves and fragments were counted following the methods described in Beyens \& Denys (1982).

Correspondence Analysis (CA) was used to explore patterns in the data. The resulting ordinations were used to define zones in the sediment core on the basis of changes in their diatom species assemblages. Only species occurring with an abundance of $1 \%$ in at least two samples were used in the study. Statistical analysis was performed using CANOCO version 4.0 (ter Braak \& Šmilauer 1998). Multivariate techniques worked with in this study are described in Jongman et al. (1995). Shannon-Wiener diversity (log-based) was calculated in R2.10.1 (R Development Core Team 2009).

The environmental reconstruction relied partly on previously developed transfer functions based on existing knowledge of the modern ecology of diatoms on Ile de la Possession and its neighbouring islands in the southern Indian Ocean in relation to soil moisture (Van de Vijver \& Beyens 1999) and temperature (Gremmen et al. 2007).

The moisture scale of Jung (1936) was used. This is an eight-point exponential moisture scale ranging from I (submerged) to VIII (completely dry), used to determine the moisture content of mosses. Although this moisture scale was qualitative, these moisture classes have been related to percentage moisture equivalents (Meisterfeld 1977). A transfer function for altitude, convertible into temperature, was developed in Gremmen et al. (2007) using the following formula: temperature $=8.263-0.0082 *$ altitude .

\section{Results}

\section{Radiometric dating}

The results of the ${ }^{14} \mathrm{C}$ dating showed an almost undisturbed stratigraphical sequence (Table I). One inversion occurred at $141 \mathrm{~cm}$ depth $\left(1270 \pm 30{ }^{14} \mathrm{C}\right.$ yr $\left.\mathrm{BP}\right)$; probably due to insufficient carbon in sample $133\left(1470 \pm 40{ }^{14} \mathrm{C}\right.$ yr BP $)$ (Mark van Strydonck, personal communication 2010). So this sample was not used in further analyses. The sedimentation 


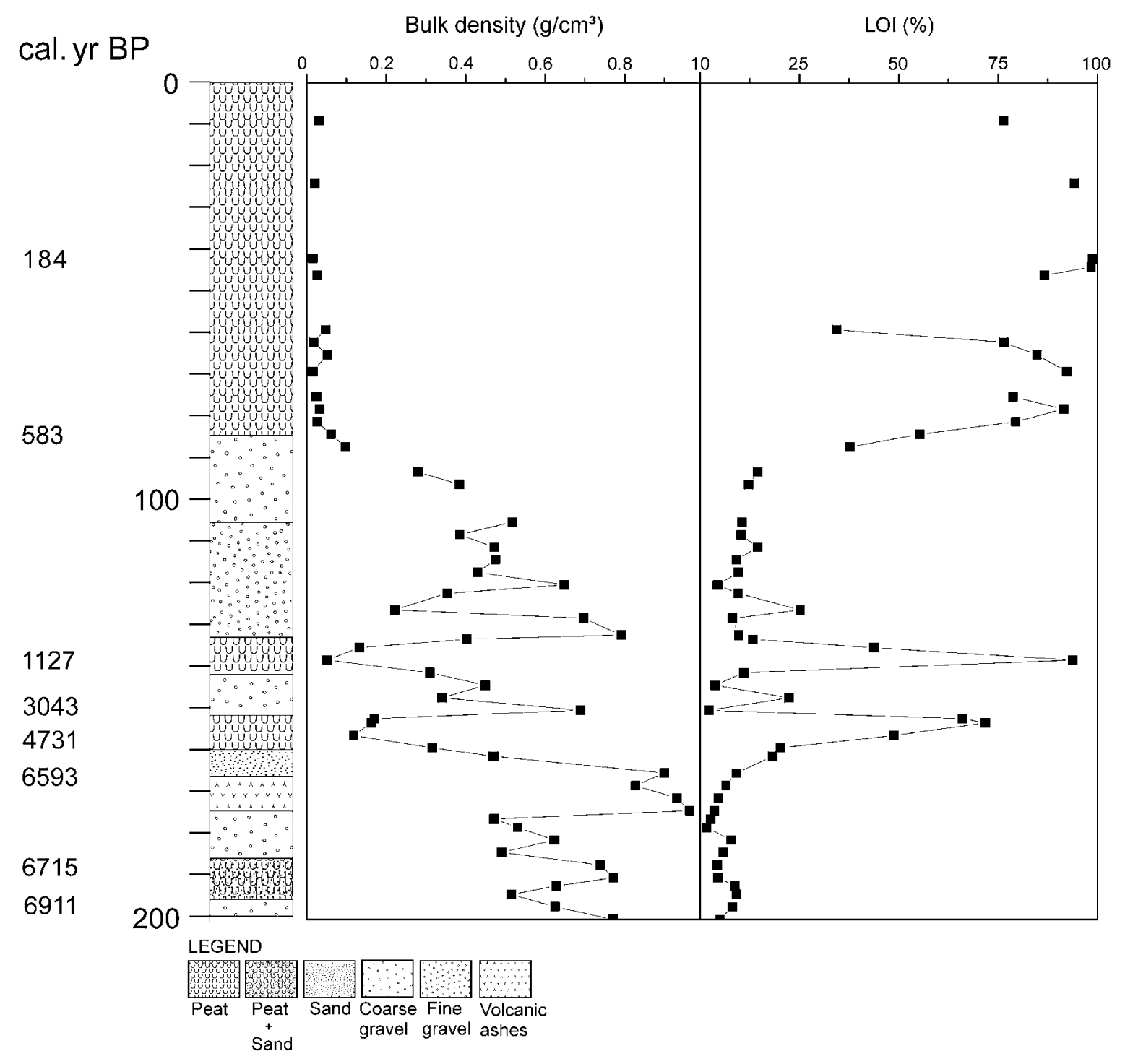

Fig. 2. Results of the different lithostratigraphical analyses. Showing (from left to right) the radiocarbon dating, sediment stratigraphy, bulk density and Loss-on-Ignition values.

rate was not uniformly changing from $0.006 \mathrm{~cm} \mathrm{yr}^{-1}$ between $5840 \pm 40{ }^{14} \mathrm{C}$ yr BP and $1270 \pm 30{ }^{14} \mathrm{C}$ yr BP and one of $0.1 \mathrm{~cm} \mathrm{yr}^{-1}$ over the last $1270 \pm 30{ }^{14} \mathrm{C}$ yr BP.

\section{Lithostratigraphic analysis}

The deepest part of the core was made up of a coarse gravel and sandy peat layer with very little organic matter $( \pm 6.5 \%$ ) (Fig. 2). A $7 \mathrm{~cm}$ thick layer of very fine-grained black tephra (volcanic ashes) was found between $174-166 \mathrm{~cm}$ and had the highest bulk density (max. $0.9 \mathrm{~g} \mathrm{~cm}^{-3}$ ). Two very small organic peat layers $(160-153 \mathrm{~cm}$ and $143-134 \mathrm{~cm})$, separated by inorganic layers of sand and coarser gravel, were recognized from their high organic matter content of $75 \%$ and $90 \%$ respectively. A thick layer of gravel $(134-85 \mathrm{~cm})$ was subdivided into a fine-grained lower part $(134-105 \mathrm{~cm})$ and a coarser fraction above $(105-85 \mathrm{~cm})$. The uppermost $85 \mathrm{~cm}$ of the core consisted almost entirely of homogenous peat containing a large amount of non-decomposed plant litter (mainly grasses and bryophytes) with an organic matter content of $80-90 \%$ and a bulk density of $0.01-0.05 \mathrm{~g} \mathrm{~cm}^{-3}$.

\section{Diatom record}

In 67 of the 71 samples counted, an abundant and wellpreserved diatom flora was found. Four samples yielded insufficient diatoms (at depths of $200 \mathrm{~cm}$ and $174-168 \mathrm{~cm}$ ) for counting. In total, 175 different taxa (including species, varieties and formas), belonging to 74 genera were observed. Although most taxa were considered to be typical freshwater taxa, 47 taxa (representing 12 genera) were identified as marine species. 


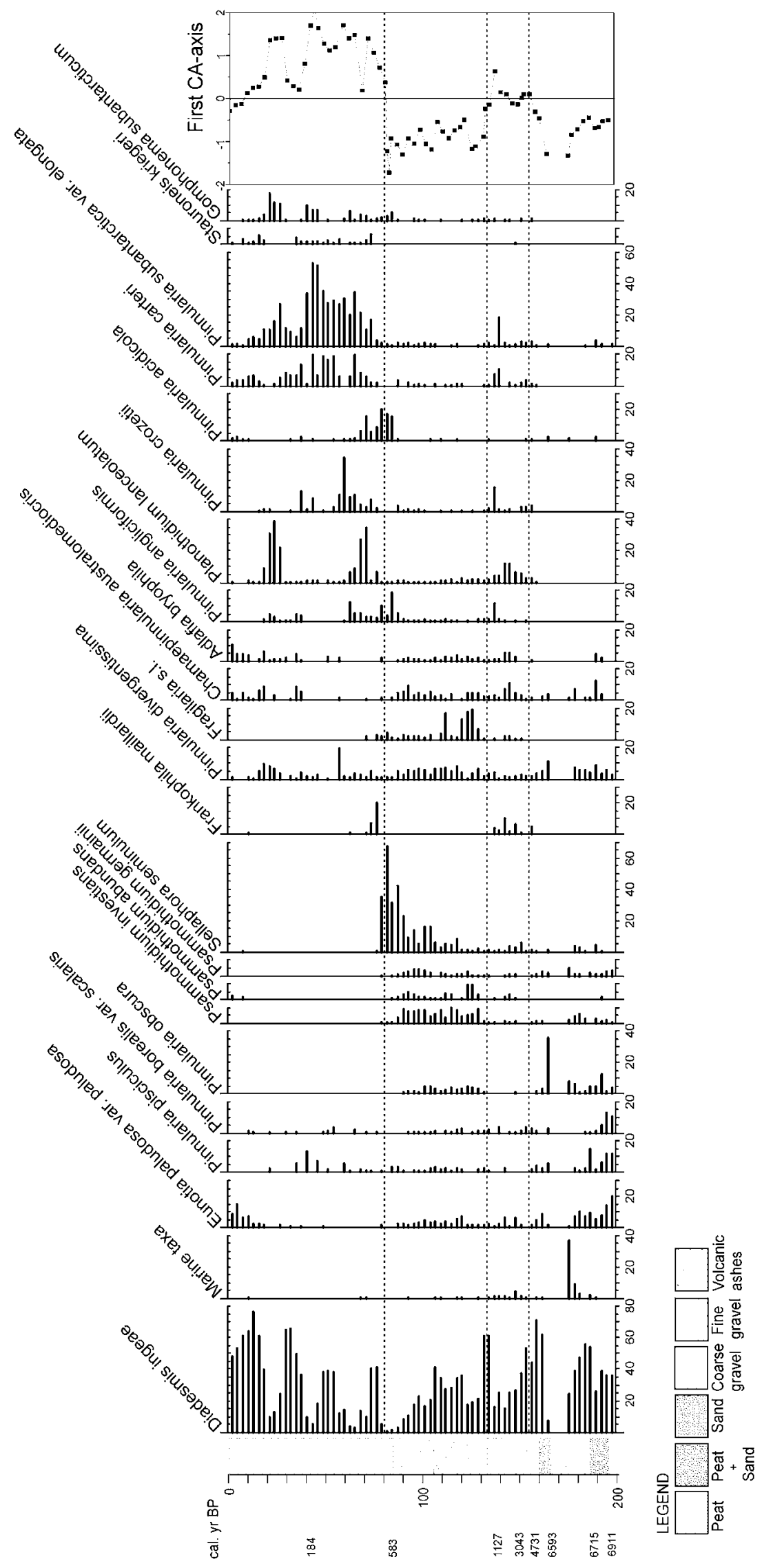

Fig. 3. Overview of the relative abundance (\%) of the most important diatom species in relation to the sediment stratigraphy. The dotted lines indicate the four MRDZ, based on Correspondence Analysis (CA). 


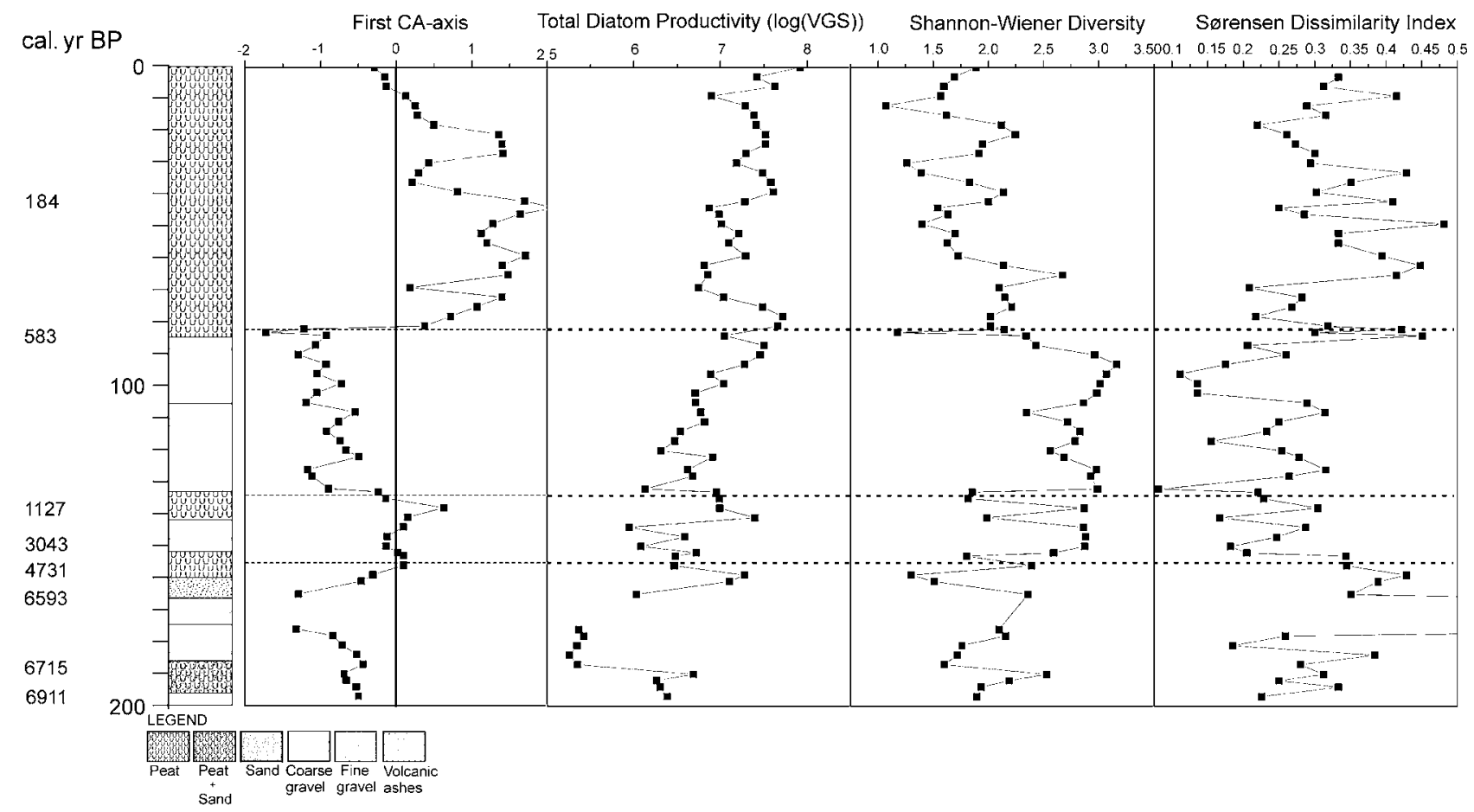

Fig. 4. Results of the Correspondence Analysis (CA), Total Diatom Productivity, Shannon Wiener Diversity and Sørensen Dissimilarity Index. The dotted lines indicate the four MRDZ.

The results of the first CA-axis suggested that the core could be subdivided into four distinct diatom zones (Morne Rouge Diatom Zones, MRDZ) (Figs 3 \& 4).

MRDZ 1 (203-156 cm, c. 6900-4731 cal. yr вP) was characterized by high abundances of Diadesmis ingeae Van de Vijver (7-71\%), Eunotia paludosa Grunow var. paludosa (1-20\%), Pinnularia pisciculus Ehrenberg sensu Van de Vijver et al. (2002a) (0-15\%), P. borealis var. scalaris (Ehrenberg) Rabenhorst (0-13\%) and Psammothidium germainii (Manguin) Sabbe (0-5\%). Several other taxa played a minor role such as Psammothidium investians (Carter) Bukhtiyarova (0-6\%), Pinnularia cf. divergentissima Grunow (0-11\%) and P. obscura Krasske (0-36\%). At $175 \mathrm{~cm}$, the proportion of marine taxa increased dramatically to almost $37 \%$. No diatoms were present in the tephra layer between 174 and $166 \mathrm{~cm}$. Immediately after this tephra layer, Pinnularia obscura occurred at its highest abundance (36\%). Both Total Diatom Productivity (TDP) (min. 5.25 $\log (\mathrm{VGS})$ ) and Sørensen Dissimilarity Index (SDI) (min. 0.18 ) increased above the tephra layer (TDP max. 7.27 $\log (\mathrm{VGS})$; SDI max. 0.43), while Shannon diversity values declined from 2.5 to 1.3 (mean 2.25). The reconstructed moisture values indicated a moist ( $F$-value 4.75$)$ to relatively dry environment ( $F$-value 7.41$)$ while the reconstructed temperature pointed towards a rather cold environment (mean $5.9^{\circ} \mathrm{C}$ ) (Fig. 5).

MRDZ 2 (156-134 cm, c. 4731-1127 cal. yr BP) had a high taxon diversity. Diadesmis ingeae dominated still (15-61\%) while the other taxa of MRDZ1 gradually disappeared. Chamaepinnularia australomediocris (Lange-Bertalot \& Schmidt) Van de Vijver (1-11\%) and Adlafia bryophila (Petersen) Lange-Bertalot (0-5\%) were subdominant. Several species such as Frankophila maillardii (Le Cohu) LangeBertalot (0-10\%), Planothidium lanceolatum (Brébisson) Lange-Bertalot (2-12\%), Pinnularia angliciformis Van de Vijver \& Beyens $(0-11 \%)$ and Pinnularia carteri Krammer $(0-10 \%)$ were present for the first time (Fig. 3). Compared to the previous zone, TDP and Shannon-Wiener diversity tended to be higher (mean TDP MRDZ 1: $6.1 \log$ (VGS) vs mean TDP MRDZ2: $6.63 \log$ (VGS); Shannon-Wiener diversity: mean 2.35) (Fig. 4). The SDI decreased (mean MRDZ1 0.43 vs mean MRDZ2 0.26). The reconstructed temperature was slightly lower (mean $5.5^{\circ} \mathrm{C}$ ) and the environment became more humid ( $F$-value 4.72$)$ (Fig. 5).

In MRDZ $3(134-83 \mathrm{~cm}, c .1127-583$ cal. yr вP) Diadesmis ingeae remained consistently present in high abundances (1-61\%), while the composition differed from the previous zone by the occurrence of Psammothidium investians (0.2-10\%), P. germainii (0-5\%), Pinnularia cf. divergentissima (1-8\%) and Chamaepinnularia australomediocris $(0-10 \%)$. Towards the end of this zone, Sellaphora seminulum (Grunow) Mann (1-42\%) became more important (Fig. 3). Total diatom productivity (ranging from 6.12 to 7.5 ) gradually increased towards the end of this zone. Both species diversity and SDI, followed the same trend as in MRDZ 2, respectively increasing 


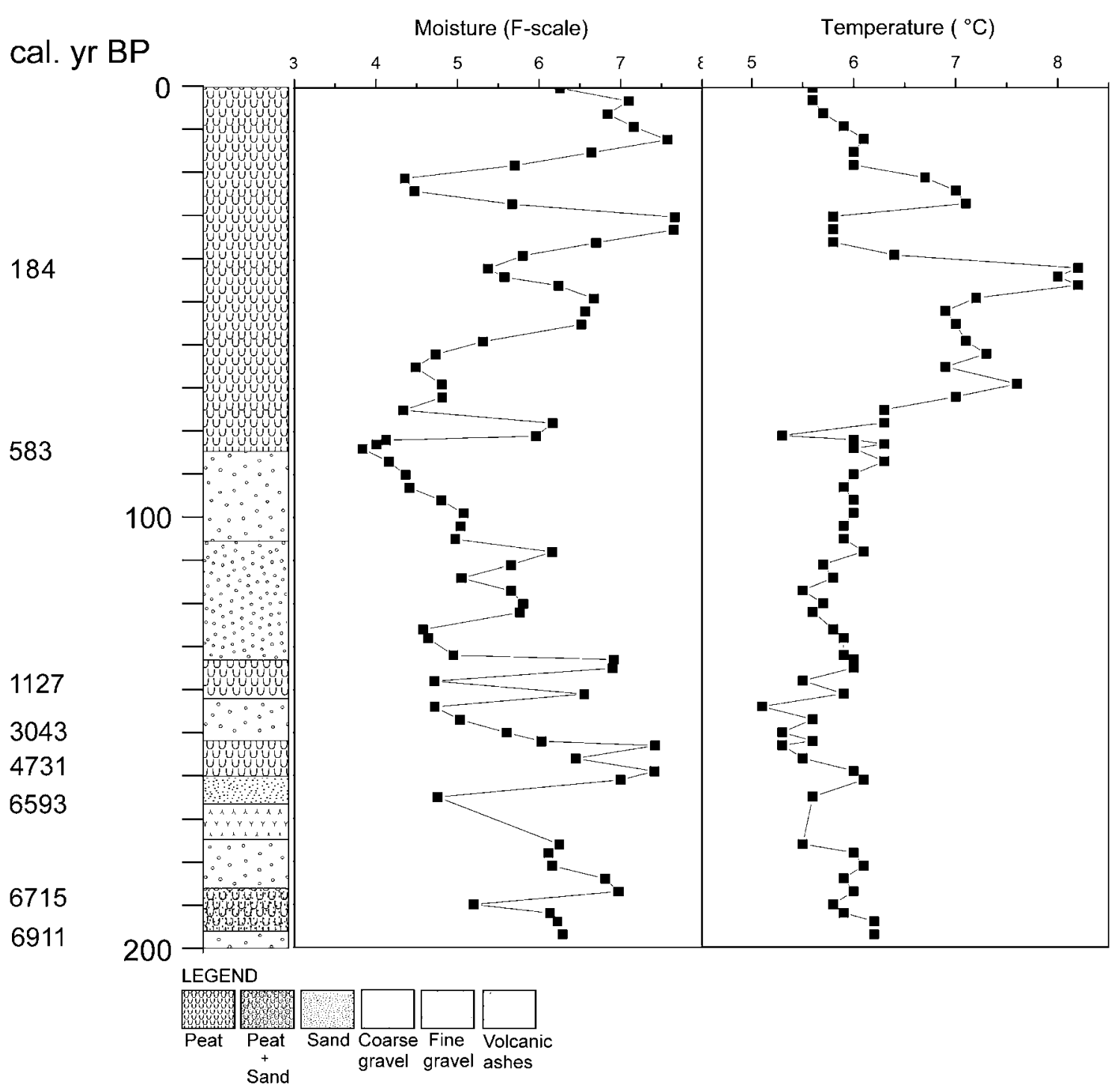

Fig. 5. Reconstructions of temperature and humidity. The dotted lines indicate the four MRDZ.

(mean 2.76) and decreasing (mean 0.24) (Fig. 4). The moisture level reached its lowest values ( $F$-value 3.8 ) while the reconstructed temperature slightly increased (mean $5.9^{\circ} \mathrm{C}$ ) pointing to slightly warmer, wetter conditions (Fig. 5).

The base of the fourth zone, MRDZ $4(83-0 \mathrm{~cm}, c .583 \mathrm{cal}$. yr BP to present), was characterized by high abundances of Sellaphora seminulum (68\%), Pinnularia angliciformis (10\%), Frankophila maillardii (20\%) and Pinnularia acidicola Van de Vijver \& Le Cohu (20\%). The proportion of Diadesmis ingeae $(0.2 \%)$ decreased significantly at the beginning of this zone but returned to higher values $(65 \%)$ after the decline of the above-mentioned taxa. Around $76 \mathrm{~cm}$, the diatom composition changed markedly. Taxa such as Pinnularia subantarctica var. elongata (Manguin) Van de Vijver \& Le Cohu (1-53\%), P. carteri (0-20\%), P. crozetii Van de Vijver $\&$ Le Cohu (0-35\%), Stauroneis kriegeri Patrick (0-6\%) and Gomphonema subantarcticum Van de Vijver \& Beyens $(0-17 \%)$ replaced all taxa from the previous zone. Planothidium lanceolatum showed two isolated peaks, one at a depth of $75 \mathrm{~cm}(35 \%)$ and another one at a depth of $24 \mathrm{~cm}$ (39\%) (Fig. 3). The TDP remained at the high level (mean $7.3 \log (\mathrm{VGS})$ ) reached at the end of the previous zone (Fig. 4). Shannon-Wiener diversity values were the lowest in this zone (mean 1.8) and SDI raised again (mean 0.32). Both reconstructed moisture and temperature showed a fluctuating pattern (Fig. 5). The first part of this zone was characterized by wetter, warmer conditions. Near the middle of this zone, the moisture started to decrease as expressed by higher $F$-values ( $F$-value max. 7.7$)$ whereas the reconstructed temperature reached its highest values $\left(8.2^{\circ} \mathrm{C}\right)$. Towards the end of this zone, values approached currently prevailing conditions. 


\section{Discussion}

The reconstruction of the palaeo-events at the coring site reveals several environmental changes that are on one hand strongly impacted by multiple local influences and on the other hand might reflect regional climatic changes. The results could only be compared with three previous studies from the Iles Crozet. The diatom-based reconstruction of the peat cores reported in Van de Vijver (1999) are based on a non-revised taxonomy (prior to 2000) making that comparison with later studies can only be based on the interpretation. The oldest parts in Vincke (2006), analysed in a core taken at $500 \mathrm{~m}$ southwards from the Morne Rouge volcano, spanning from $8400{ }^{14} \mathrm{C}$ yr BP to around $5400{ }^{14} \mathrm{C}$ yr BP. Although a tephra layer was not reported, a recent reanalysis of the core indicated a small (5 $\mathrm{mm}$ wide) tephra layer (Van de Vijver, personal observation). The core analysed in Van der Putten et al. (2008), was taken in the centre of the Morne Rouge crater spanning about $6400 \mathrm{cal}$. yr BP. On the nearby Iles Kerguelen, Frenot et al. (1997) reported several climatic changes as indicated by the retreat of a glacier on the island.

Based on the obtained results and a comparison with the regional studies, the main features of our palaeoenvironmental reconstruction are described below.

\section{Morne Rouge volcano eruption}

The oldest records in the Morne Rouge sediment core (c. $6900 \mathrm{cal}$. yr BP) point to the presence of a rather acid, dry environment dominated by a dry moss tundra, presenting similar conditions to the present situation at Vallée des Branloires. The dominance of taxa such as Diadesmis ingeae, Eunotia paludosa var. paludosa, Pinnularia pisciculus, Pinnularia borealis var. scalaris and Psammothidium germainii clearly confirm this observation (Van de Vijver et al. 2002). The short appearance of Adlafia bryophila and Chamaepinnularia australomediocris, both favouring semiwet, nutrient-poor conditions, is probably the result of the inflow of hillslope material onto the coring site, as is also confirmed by a higher amount of coarse gravel in the core.

The sudden increase in the relative abundance of marine valves, right before the occurrence of a $7 \mathrm{~cm}$ thick tephra layer, indicates the beginning of a dramatic event that took place at the coring site. Dominant genera include Cocconeis, Fragilariopsis and Thalassiosira. While the first is a typical epiphytic genus, the latter two are known for their pelagic life form within the Polar Front Zone (Medlin \& Priddle 1990, Crosta et al. 2005). Considering the large diversity of marine taxa (47 out of 175), the high proportion present during only a very short period, the good preservation of the valves and the almost complete absence of marine valves in the rest of the core, passive wind-driven transport should be excluded. More probably, the presence of the tephra layer, points to a sudden subaqueous volcanic eruption (Gerald Ernst, personal communication 2010) of the Morne Rouge volcano between
$6715 \pm 42$ and $6593 \pm 60$ cal. yr BP. Our interpretation is that the volcanic eruption caused a sudden flooding of the coring area by seawater. It is well known that eruptions of subaqueous volcanoes can generate tsunami waves (Egorov 2007) and at the relatively low altitude of the coring site on the Morne Rouge volcano (12 $\mathrm{m}$ a.s.l.) the link to such a tsunami wave is highly likely. Then, the homogeneous tephra layer was probably deposited during a single eruption, as no diatom remains were found (depths 168, 171, $174 \mathrm{~cm}$ ). Giret et al. (2003) and Van der Putten et al. (2008) stated that the last (Strombolian) volcanic phase (phase V) on Ile de la Possession (including the formation of Morne Rouge, Mont Branca and Mont des Cratères) took place between 10000 and $5800{ }^{14} \mathrm{C}$ yr BP. Our data now constrain the Morne Rouge volcanic eruption to the period c. 6700-6600 cal. yr BP. The palaeo-reconstruction in Van der Putten et al. (2008), based on three cores taken in the lake located in the crater, starts at $6485 \mathrm{cal}$. yr BP, and corresponds to the end of the volcanic eruption, as inferred from our data. Based on the presence of the tephra layer, the absence of raised beaches (Van de Vijver, personal observation) in the area and the absence of evidence in the diatom data for a more long-lasting marine event at the coring site, a relative sea level change at that period can be excluded. Moreover, data from other Antarctic localities place relative sea level rises much earlier in time (Verleyen et al. 2005).

\section{Mid-Holocene cooling event}

After the volcanic eruption, sedimentation rates declined and less than $30 \mathrm{~cm}$ was deposited over more than 4000 years. The tephra was rapidly colonized by Pinnularia obscura, a pioneer species (Krammer 2000). Several diatom species, present before the volcanic eruption, reappeared at the coring site, indicating a gradual re-establishment of the dry moss tundra. The overall dominance of Diadesmis ingeae (up to $70 \%$ ), typical for very dry, terrestrial circumstances (Van de Vijver et al. 2002) and the lack of a high sedimentation rate is interpreted as the result of a dry, cooler, less productive period. This finding is consistent with some studies, based on both marine and terrestrial evidence, which suggest that there was a cooling in the Southern Hemisphere between 6000 and 3000 cal. yr BP. For example, in the terrestrial record of Van der Putten et al. (2008) a period of lower biological production is observed, similar to our results, pointing towards a colder (and/or wetter) climate from c. $5560 \mathrm{cal}$. yr BP. Two terrestrial studies from the neighbouring Iles Kerguelen show evidence for a colder period (Bellair-Roche 1976a, Young \& Schofield 1973) whereas on the sub-Antarctic Campbell Island (located between New Zealand and the Antarctic Continent) a cool period was recorded based on pollen data (McGlone et al. 2010). Nielsen et al. (2004) concluded from the analysis of their Holocene marine cores in the South Atlantic sector of the Southern Ocean, that a cooler period occurred between 6000 and 3000 cal. yr BP. 


\section{Late Holocene warm period}

Around 3050 cal. yr BP, the increase in diatom diversity caused by a sudden appearance of a high number of taxa indicates a major shift in environmental conditions, probably caused by changing climatic circumstances. The diatom record points to wetter and even warmer conditions, as taxa such as Chamaepinnularia australomediocris, Frankophila maillardii, Adlafia bryophila and Planothidium lanceolatum (Van de Vijver et al. 2002, Gremmen et al. 2007) start to dominate the flora. The occurrence of several zones of gravel and fine-grained material, resulting in a sudden decrease of organic matter and an increase of bulk density may be the result of wetter and/or windier climatic conditions at the island. Van der Putten et al. (2008) found a similar signal with wetter conditions around the same time in the Morne Rouge lake sediments although they related these conditions more to an intensification of the Southern westerlies and less to a more global warming. Evidence of a warmer period between $2400-2190{ }^{14} \mathrm{C}$ yr BP was also found in Van de Vijver (1999). The short but distinct occurrences of Fragilaria s.l. and Frankophila maillardii, known to prefer almost exclusively lotic conditions on the sub-Antarctic islands (Van de Vijver \& Beyens 1999, Van de Vijver et al. 2001) supports the hypothesis of temporary increased erosion and slow run-off towards the coring site. These results may correspond to a more general late Holocene climatic optimum, reported from several locations in the sub-Antarctic region. On nearby Kerguelen, glaciers retreated between 2400 and 1000 cal. yr BP, probably indicating a warming period (Frenot et al. 1997). McGlone et al. (2010) found a similar warming trend from c. 1700-700 cal. yr BP on Campbell Island. In the Antarctic Peninsula Region, Jones et al. (2000) and Hodgson \& Convey (2005) described a warmer, more productive period based on pollen and diatom results lasting until c. 1400 cal. yr BP followed by a cooling event. Many studies from the Antarctic Continent report the occurrence of a warmer period between 4000 and 2000 cal. yr BP inferred from various ice, marine and lake cores but a distinct neoglacial cooling starting around 2000 cal. yr BP (Verleyen et al. 2010).

\section{Past 600 years}

Around 600 cal. yr BP, D. ingeae gradually disappears and the subsequent dominance of Sellaphora seminulum, Pinnularia angliciformis, P. acidicola and Psammothidium investians points to the presence of wet soil with an increase in nutrients. It is, however, not entirely clear whether this increase is the result of a climatic change followed by a higher productivity or the result of an increased input of nutrients by marine mammals and/or birds. In elephant seal wallow areas, several of these species dominate the diatom flora (Van de Vijver et al. 2002). Elephant seals can nowadays still be found on the small plateaus on the Morne Rouge slopes during their moulting period and their influence of the soil is very distinct (Van de Vijver, personal observation). Analysis of peat cores taken in the southern part of the Vallée des Branloires where elephant seals are absent, might clarify this problem (Van de Vijver, unpublished results). The marked increase of $S$. seminulum in combination with an almost complete absence of more terrestrial species such as D. ingeae, P. obscura and the different Psammothidium species near the end of this period reflects much wetter conditions that abruptly come to an end.

During the last $400 \mathrm{cal}$. yr BP, the diatom evidence probably reflects very local biotic influence, obscuring the climatic signal. Moravcová et al. (2009) found a comparable diatom composition near occupied wandering albatross (Diomedea exulans) nests at different nesting sites on Ile de la Possession. It is possible that the coring site was used by one or more wandering albatross pairs as a nesting ground, altering significantly the environmental conditions at this site. Nowadays, several nests of wandering albatrosses are still present on the slopes of the Morne Rouge (Van de Vijver, personal observation) but there is no visual evidence of large ancient albatross nesting grounds on the site making it very likely that the influence was limited to the proximity of a single nesting pair that did not continuously impact the site since the taxa preferring higher nutrient conditions, such as Pinnularia subantarctica var. elongata, Pinnularia carteri, Stauroneis kriegeri and Gomphonema subantarcticum, alternate with $D$. ingeae, known to avoid enriched soils (Moravcová et al. 2009). The biotic influence by other animals can be excluded. Although Planothidium lanceolatum was often found in soils near penguin rookeries, the topography of the site does not support the presence of large numbers of penguins since they use bare ground, sandy beaches or rocky slopes to incubate their eggs (Boersma 2008). The very low number of $P$. angliciformis typically present in elephant seal wallows and the absence of other typical wallow species such as Sellaphora seminulum and Staurosirella pinnata (Ehrenberg) Williams \& Round (Van de Vijver et al. 2002), do not indicate large elephant seal numbers.

Around 100 cal. yr BP ago, the importance of the nutrientrich diatom community declined with many species disappearing being replaced by more aerophilic, oligotrophic species reflecting the present-day diatom community typical for dry, peaty valley slopes in the Vallée des Branloires.

\section{Conclusion}

The present study reconstructed several major environmental changes on Ile de la Possession during the past 7000 years. A tephra layer, containing no diatoms, constrains the eruption of the Morne Rouge volcano between 6700-6600 cal. yr BP. The presence of a marine diatom rich layer just below the tephra is interpreted as a marine flooding event associated with the volcanic eruption. Sediments on top of the tephra layer indicate a gradual recolonization signal by terrestrial diatoms.

Using transfer functions for temperature and moisture, evidence is presented of the late climatic optimum 
around 3050 cal. yr BP, preceded by a cooling event until $6600 \mathrm{cal}$. yr BP. The reconstruction of the past $600 \mathrm{cal}$. yr вP has been obscured by an increased biotic impact of both elephant seals and wandering albatrosses.

\section{Acknowledgements}

This study was made possible by the DIVCRO 405 project (2004-05) funded by the French Polar Institute IPEV. Drs S. Vincke, S. Geiger and G. Conan are thanked for their help during the sediment core drilling on the island. Furthermore, we sincerely thank Dr N. Gremmen for the use of his transfer function for temperature. Also thanks to Mark van Strydonck, KIKIRPA, for the radiometric dating, and Professor Dr G. Ernst who has identified the origin of the tephra. We also thank the two reviewers whose comments helped to improve this manuscript.

\section{References}

Bellair-Roche, N. 1972. Palynological study of a peat bog in Vallée des Branloires, Ile de la Possession. In AdIE, R.J., ed. Antarctic geology and geophysics. Oslo: Universitetsforlaget, 831-834.

Bellair-Roche, N. 1976a. L'holocène de l'anse Betsy (Ile Kerguelen). Comptes Rendus de l'Académie des Sciences de Paris, série D, 282, 1347-1349.

Bellair-Roche, N. 1976b. Les variations climatiques de l'holocène supérieur des îles Kerguelen: d'après la coupe d'une tourbière de la plainte de Dante (côte méridionale). Comptes Rendus de l'Académie des Sciences de Paris, série D, 282, 1257-1260.

Bellair-Roche, N. \& Delibrias, G. 1967. Variations climatiques durant le dernier millénaire aux ïles Kerguelen. Comptes Rendus de l'Académie des Sciences de Paris, série D, 264, 2085-2088.

Bentley, M.J., Hodgson, D.A., Smith, J.A., Ó Cofaigh, C., Domack, E.W., Larter, R.D., Roberts, S.J., Brachfeld, S., Leventer, A., Huort, C., Hillenbrand, C.-D. \& Evans, J. 2009. Mechanisms of Holocene palaeoenvironmental change in the Antarctic Peninsula region. The Holocene, 19, 51-69.

Beyens, L. \& Denys, L. 1982. Problems in diatom analysis of deposits Allochtonous valves and fragmentation. Geologie en Mijnbouw, 61, $159-162$.

Boersma, P.D. 2008. Penguins as marine sentinels. Bioscience, 58, 597-607.

Bronk-RAmSey, C. 2009. Bayesian analysis of radiocarbon dates. Radiocarbon, 51, 337-360.

Crosta, X., Romero, O., Armand, L.K. \& Pichon, J.J. 2005. The biogeography of major diatom taxa in Southern Ocean sediments: 2. Open ocean related species. Palaeogeography, Palaeoclimatology, Palaeoecology, 223, 66-92.

Egorov, Y. 2007. Tsunami wave generation by the eruption of underwater volcano. Natural Hazards and Earth System Sciences, 7, 65-69.

FRENOT, Y. 1986. Interactions entre la faune lombricienne et les systèmes édaphiques d'une île subantarctique:Ile de la Possession, Archipel Crozet. $\mathrm{PhD}$ thesis, Université de Rennes, 358 pp. [Unpublished].

Frenot, Y., Gloaguen, J.C., Masse, L. \& Lebouvier, M. 2001. Human activities, ecosystem disturbance and plant invasions in subantarctic Crozet, Kerguelen and Amsterdam islands. Biological Conservation, 101, 33-50.

Frenot, Y., Gloaguen, J.C., van De Vijver, B. \& Beyens, L. 1997. Datation de quelques sédiments tourbeux holocènes et oscillations glaciaires aux îles Kerguelen. Comptes Rendus de l'Académie des Sciences de Paris, 320, 567-573.

Giret, A., Weis, D., Zhou, X., Cottin, J.Y. \& Tourpin, S. 2003. Géologie des îles Crozet. Géologues, 137, 15-23.

Gremmen, N.J.M., van De Vijver, B., Frenot, Y. \& Lebouvier, M. 2007. Distribution of moss-inhabiting diatoms along an altitudinal gradient at sub-Antarctic Iles Kerguelen. Antarctic Science, 19, $17-24$.

Hodgson, D.A. \& Convey, P. 2005. A 7000-year record of Oribatid mite communities on a maritime-Antarctic island: responses to climate change. Arctic, Antarctic and Alpine Research, 37, 239-245.

Hodgson, D.A. \& Sime, L.C. 2010. Southern westerlies and $\mathrm{CO}_{2}$. Nature Geoscience, 3, 666-667.

Hodgson, D.A., Doran, P.T., Roberts, D. \& McMinn, A. 2004. Paleolimnological studies from the Antarctic and sub-Antarctic islands. In Pienitz, R., Douglas, M.S.V. \& Smol, J.P., eds. Long-term environmental change in Acrtic and Antarctic lakes. Dordrecht: Kluwer, 419-474.

Ingólfsson, Ó., Huort, C., Berkman, P.A., Svante, B., Colhoun, E., Goodwin, I.D., Hall, B., Hirakawa, K., Melles, M., Möller, P. \& Prentice, M.L. 1998. Antarctic glacial history since the Last Glacial Maximum: an overview of the record on land. Antarctic Science, 10, 326-344.

Jones, V.J., Hodgson, D.A. \& Chepstow-Lusty, A. 2000. Palaeolimnological evidence for marked Holocene environmental changes on Signy Island, Antarctica. Holocene, 10, 43-60.

Jongman, R.H.G., Ter BraAk, C.J.F. \& van Tongeren, O.F.R. 1995. Data analysis in community and landscape ecology. Cambridge: Cambridge University Press, 299 pp.

JUNG, W. 1936. Thecamöben unsprünglicher lebender deutscher Hochmoore. Abhandlungen Landesmus Naturkunde Muester Westfalen, 7, 1-87.

Krammer, K. 2000. Diatoms of Europe. Diatoms of the European inland waters and comparable habitats. Vol. 1. The genus Pinnularia. Ruggell: Gantner, 703 pp.

LARson, D.D. 1974. Paleoecological investigations of diatoms in a core from Kerguelen Islands, Southeast Indian Ocean. Ohio, OH: Ohio Statue University, Institute of Polar Studies, Report no. 50, $70 \mathrm{pp}$.

LAST, W.M. \& SMOL, J.P. 2001. Tracking environmental change using lake sediments. Volume 2: Physical and geochemical methods. Dordrecht: Kluwer, 528 pp.

McCormac, F.G., Hogg, A.G., Blackwell, P.G., Buck, C.E., Higham, T.F.G. \& Reimer, P.J. 2004. SHCal04 Southern Hemisphere Calibration 0-11.0 cal. kyr BP. Radiocarbon, 46, 1087-1092.

McGlone, M.S., Turney, C.S.M., Wilmshurst, J.M., Renwick, J. \& PahnKe, K. 2010. Divergent trends in land and ocean temperature in the Southern Ocean over the past 18,000 years. Nature Geoscience, 10.1038/NGEO931.

Meduin, L.K. \& Priddle, J. 1990. Polar marine diatoms. Cambridge: British Antarctic Survey, 214 pp.

Meisterfeld, R. 1977. Horizontal and vertical distribution of Testacea (Rhizopoda-Testacea) in Sphagnum. Archiv Fur Hydrobiologie, 79, 319-356.

Moravcová, A., Beyens, L. \& van de ViJver, B. 2009. Diatom communities in soils influenced by the wandering albatross (Diomedea exulans). Polar Biology, 33, 241-255.

Nielsen, S.H.H., Koç, N. \& Crosta, X. 2004. Holocene climate in the Atlantic sector of the Southern Ocean: controlled by insolation or ocean circulation? Geology, 32, 317-320.

PahnKe, K. \& Sachs, J.P. 2006. Sea surface temperatures of southern midlatitudes $\quad 0-160$ kyr BP. Paleoceanography, 21, 10.1029/ $2005 \mathrm{pa} 001191$.

R Development Core Team 2009. R: a language and environment for statistical computing. Vienna: R Foundation for Statistical Computing, http://www.R-project.org. 
StockmarR, J. 1971. Tablets with spores used in absolute pollen analysis. Pollen Spores, 13, 615-621.

Stoermer, E.F. \& Smol, J.P. 1999. The diatoms: applications for the environmental and earth sciences. Cambridge: Cambridge University Press, 469 pp.

Stott, L.D., Timmermann, A. \& Thunell, R. 2007. Southern Hemisphere and deep-sea warming led deglacial atmospheric CO. Science, 318, 435-438.

Ter Braak, C.J.F. \& Šmilauer, P. 1998. CANOCO reference manual and user's guide to Canoco for Windows: software for Canonical Community Ordination (ver. 4). Ithaca, NY: Microcomputer Power, $352 \mathrm{pp}$.

VAN DE VIJVER, B. 1999. A Protistologival approach of the ecology and palaeo-ecology of the Subantarctic and Maritime Antarctic Region. $\mathrm{PhD}$ thesis, University of Antwerp, $278 \mathrm{pp}$.

VAn de ViJver, B. \& Beyens, L. 1999. Moss diatom communities from Ile de la Possession (Crozet, Subantarctica) and their relationship with moisture. Polar Biology, 22, 219-231.

Van de Vijver, B., Frenot, Y. \& Beyens, L. 2002. Freshwater diatoms from Ile de la Possession (Crozet Archipelago, Subantarctica). Berlin: J. Cramer, 412 pp.

VAn de ViJver, B., Ledeganck, P. \& Beyens, L. 2001. Habitat preferences in freshwater diatom communities from sub-Antarctic Iles Kerguelen. Antarctic Science, 13, 28-36.

Van der Putten, N., Stieperaere, H., Verbruggen, C. \& Ochyra, R. 2004. Holocene palaeoecology and climate history of South Georgia (subAntarctica) based on a macrofossil record of bryophytes and seeds. Holocene, 14, 382-392.
Van Der Putten, N., Hebrard, J.P., Verbruggen, C., van De Vijver, B., Disnar, J.R., Spassov, S., De Beaulieu, J.L., De Dapper, M., Keravis, D., Hus, J., Thouveny, N. \& Frenot, Y. 2008. An integrated palaeoenvironmental investigation of a 6200 year old peat sequence from Ile de la Possession, Iles Crozet, sub-Antarctica. Palaeogeography, Palaeoclimatology, Palaeoecology, 270, 179-195.

VAN DER WERFF, A. 1955. A new method of concentrating and cleaning diatoms and other organisms. Verhandlungen der Internationalen Vereinigung für Theoretische und Angewandte Limnologie, 12, 276-277.

Verleyen, E., Hodgson, D.A., Milne, G.A., Sabbe, K. \& Vyverman, W. 2005. Relative sea-level history from the Lambert Glacier region, East Antarctica, and its relation to deglaciation and Holocene glacier readvance. Quaternary Research, 63, 45-52.

Verleyen, E., Hodgson, D.A., Sabbe, K., Cremer, H., Emslie, S.D., Gibson, J., Hall, B., Imura, S., Kudoh, S., Marshall, G.J., Mcminn, A., Melles, M., Newman, L., Roberts, D., Roberts, S.J., Singh, S.M., Sterken, M., Tavernier, I., Verkulich, S., van De Vyver, E., van Nieuwenhuyze, W., Vyverman, W. \& Wagner, B. 2010. Post-glacial regional climate variability along the East Antarctic coastal marginevidence from shallow marine and coastal terrestrial records. Earth Science Reviews, 10.1016/j.earscirev.2010.10.006.

VINCKE, S. 2006. Diversity and ecology of the testate amoebae fauna of Ile de la Possession (Crozet Archipelago, sub-Antarctica). PhD thesis, University of Antwerp, 260 pp. [Unpublished].

Young, S.B. \& Schofield, E.K. 1973. Pollen evidence for Late Quaternary climate changes on Kerguelen Islands. Nature, 245, 311-312. 